\title{
TPMT wt Allele
}

National Cancer Institute

\section{Source}

National Cancer Institute. TPMT wt Allele. NCI Thesaurus. Code C45688.

Human TPMT wild-type allele is located in the vicinity of 6 p22.3 and is approximately 26 $\mathrm{kb}$ in length. This allele, which encodes thiopurine S-methyltransferase protein, is involved in the S-methylation of thiopurine drugs. Certain allelic variants of the TPMT gene are associated with either decreased gene expression or reduced enzymatic activity of their corresponding protein products. 